\title{
高須賀沼表水嚈に出現した水素イオン 濃度逆轉の小成層と水中の瓦斯代謝
}

\author{
菖原健 \\ (東 京菏 等 學，校)
}

〔插圆 3 , 表 5〕

(昭和 15 年 3 月 2 日受鐼)

Dichotomous Micro-stratification of the pHI developed in Takasuka-numa and the Gaseous Metabolism By Ken Sugawara.

目狄

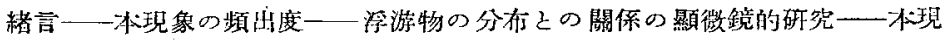
象と水明の全炭酸量の變斯

\section{緒言}

從來諸種の湖沼因子の强度つ垂直變化の測定は metre を單位として $1 \mathrm{~m}$, $5 \mathrm{~m}, 10 \mathrm{~m}$ といいつを間隔老以て測定されて來て居るので，それよりも細か く，例へば $50 \mathrm{~cm}$ の間隔を以てした測定の如きなその例が少いものであつ

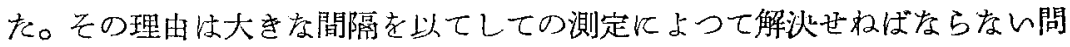
題が澤山あつたのと文他方には從來の力法をとのま」踏警したのでは正し く細かん測定を行ふ事が出來ないと方ふ样な理由がすつたをめである。實際 エッタマン式探水器や北原式採水器ではそれらの器の大きさいためとそれの

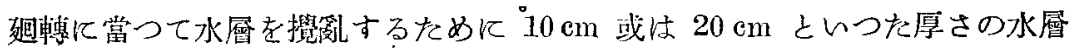

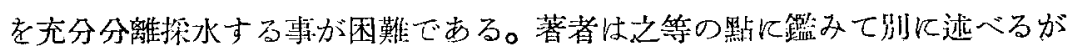

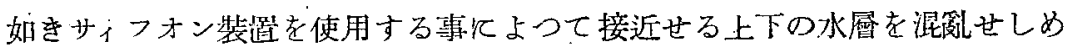

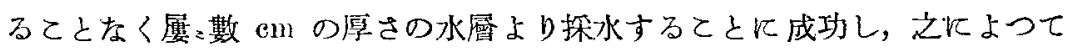
從來比して一段細加い水曆差に於ける湖沼因子の分有變動炕關する知識を 獲得するととを試みるととにした。 
一玆に逝べる pH 逆轉の小成層なる現象は全くかつる方法を探用したがため に發見の機會を見出しをものである。

即方著者住 1938 年 7 月か力る探水方法に上り埼玉䅫高須賀沼飞於て最 小 $5 \mathrm{~cm}$ の閒隔を以て $\mathrm{pH}$ 及び溶在酸紊量を測定して次の如き結果江到逛し $\hbar(1)$ 。

第 1 斌

\begin{tabular}{|c|c|c|c|c|c|c|c|c|c|c|c|c|c|c|}
\hline \multirow[b]{2}{*}{$\begin{array}{l}\text { Deptli } \\
\text { m. }\end{array}$} & \multicolumn{3}{|c|}{$\mid \begin{array}{l}\text { July } 29,1938 \\
5.15-6.20 \text { P.M. }\end{array}$} & \multicolumn{8}{|c|}{$\begin{array}{c}\text { July } 30,193 \mathrm{~S} \\
6.20-7.30 \text { A.M. } \\
1.00-2.50 \text { P.M. } 5.10-6.30 \text { P.M. }\end{array}$} & \multicolumn{3}{|c|}{$\begin{array}{l}\text { July } 31,1938 \\
6.50-7.30 \mathrm{~A} . \mathrm{M} \text {. }\end{array}$} \\
\hline & 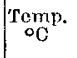 & $\mathrm{pH}$ & $\begin{array}{c}\text { Oxygen } \\
\text { (c.c. } 11 .)\end{array}$ & $\underset{{ }^{2} \mathrm{C}}{\text { Temp. }}$ & $\mathrm{p} 1 \mathrm{I}$ & $\begin{array}{c}\text { Oxygen } \\
\text { (c.c. } 11 .)\end{array}$ & $\mathrm{pH}$ & $\begin{array}{l}\text { Oxygen } \\
\text { (c.c.j1.) }\end{array}$ & 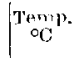 & pII & $\begin{array}{l}\text { Oxrgen } \\
(0.6 / 1)\end{array}$ & Temp. & ${ }^{p} \amalg$ & $\begin{array}{l}\text { Oxygen } \\
\text { (c.e.j1.) }\end{array}$ \\
\hline 0 & 31.15 & 7.5 & 5.83 & & 7.3 & 5.37 & 7.5 & 6.12 & 30.58 & 7.7 & $7 \quad 6.24$ & 27.5 & 7.0 & 4.97 \\
\hline 1.00 & & 7.5 & 5.84 & 28.00 & 7.3 & 5.26 & 7.5 & 5.88 & 28.52 & 7.5 & $\begin{array}{ll}5 & 6.02\end{array}$ & 28.0 & 7.0 & 5.01 \\
\hline 1.05 & & 7.5 & & & & & 7.3 & & & & & & & \\
\hline 1.10 & & 7.2 & & & & & 7.1 & & & & & & & \\
\hline 1.15 & & 6.9 & - & $\cdot$ & & & .7 .1 & & & & & & & \\
\hline 1.20 & & 6.9 & & & & & & & & & & & & \\
\hline 1.25 & & 6.5 & & & 7.3 & & 6.9 & & & 6.7 & & & & \\
\hline 1.30 & & 6.5 & & . & & . & & & & & & & & \\
\hline 1.40 & . & 6.9 & & & · & & & & & & & & & \\
\hline 1.50 & 27.40 & 7.1 & 5.40 & & 7.1 & 5.07 & 6.7 & 4.86 & 27.35 & 6.5 & 4.09 & & 6.9 & \\
\hline 1.60 & & & 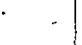 & & 、 & & & & & 6.7 & & & & \\
\hline 1.75 & & & & & 6.8 & 4.42 & 6.9 & 5,26 & & 6.9 & & & & \\
\hline 1.90 & & & & & & & 6.7 & 4.61 & & & & & & \\
\hline 2.00 & & 6.5 & 2.98 & 26.26 & 6.5 & 3.52 & 6.7 & 4.50 & 26.00 & 6.7 & 4.92 & 26.2 . & 6.6 & 364 \\
\hline 2.5 & & & & & 6.3 & & 6.3 & 2.07 & & 6.3 & 1.94 & & & \\
\hline 30 & 20.88 & 6.2 & 0.29 & 21.80 & 6.2 & & 6.1 & 0.35 & 21.30 & 6.1 & $\cdot 0.33$ & 24.2 & 6.2 & 0.35 \\
\hline 4.0 & 20.80 & 6.4 & 0.06 & & 6.3 & & & & & & & 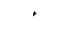 & . & \\
\hline 5.0 & 18.46 & 6.9 & & & & & & & & & & & & \\
\hline
\end{tabular}

7 月 29 日夕 $1.05 \mathrm{~m}$ 上り $1.25 〜 1.30 \mathrm{~m}$ 亿向つて $\mathrm{pH}$ が減少してなで極 小值に達しそれより再び增加して $1.5 \mathrm{~m}$ の.7.1. 亿及び再び減少して $3.0 \mathrm{~m}$ の 62 の極小做に達し然る後 $5.0 \mathrm{~m}$ の 6.9 飞䁌加するのを見た。との二つ の極小做の中 $3.0 \mathrm{~m}$ の8の壮古くより知られてるを型式のもので本邦の湖沼 次數多く見られるものである。 


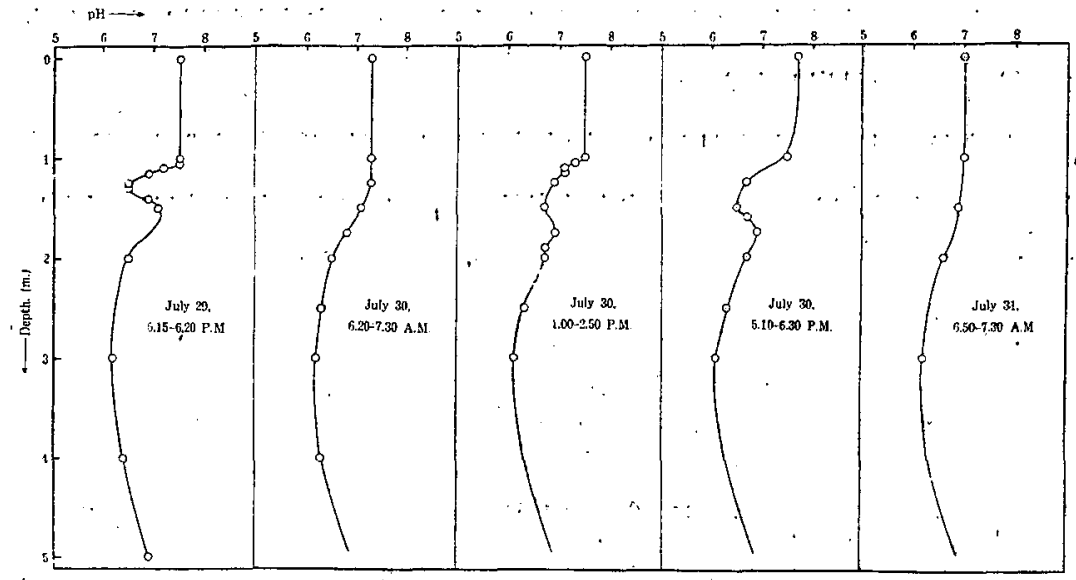

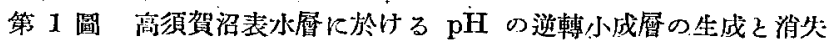
(1938 年 7 月 29-31 日)

之に反して始のもの泣從來認知されて居なかつた岁のである。尤も從來で

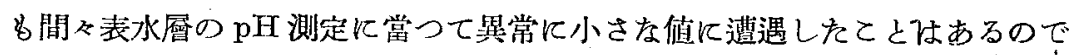
あるが探水し直してみると再びは見られ亦との何者をるか炕就ては疑問を持 たれ乍ら全く想像も出來なかつたのである。之は今日になつてみると探水器

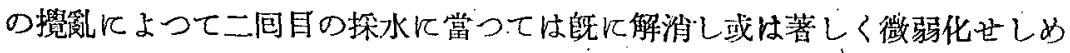
られたつめと見られるのである。

とてろで忽朝になつてみると前夕 $1.25 \mathrm{~m}$ に見られた $\mathrm{pH}$ 極小は消头して

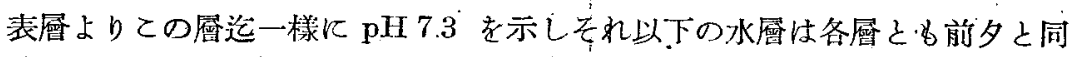
じ pH を示した。

之によつて見れば夜間の冷却によつて $1.5 \mathrm{~m}$ 迄上下水の混合が起りそれが 爲にとの水層迄は $\mathrm{pH}$ 成層が解消したものと見られるのである。

次に 30 日書には朝に對し $0 \mathrm{~m}, 1 \mathrm{~m}, 1.75 \mathrm{~m}$ 及び $2.0 \mathrm{~m}$ では $\mathrm{pH}$ が塯加

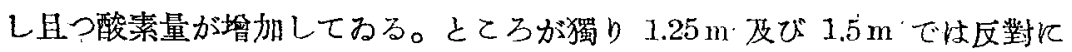
pH が減少し1.5 m では酸素も減少してわる。

各水腐に於げる酸素量の增加之 $\mathrm{pH}$ 增加とは植物性プランクトンの炭酸 同化作用に基づくととが明かであり丈その同化作用は日光炤度と共に隇少す

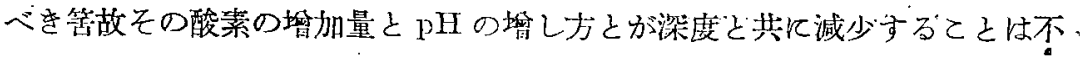


思議でない。然るに $1.75 \mathrm{~m}, 2.00 \mathrm{~m}$ 等で何酸素の增加と $\mathrm{pH}$ の增加が見ら れるのにそれより表層に近い $1.50 \mathrm{~m}$ の如きでそれらの咸少が見られたてと． は二寸意外の事實である。

この異常なる $\mathrm{pH}$ と酸索量の減少は引續して夕刻迄進行し逐に $1.5 \mathrm{~m}$ の $\mathrm{pH}$ は 6.5 飞到り酸素量は 4.09 c.c./1 飞迄減少し，て〉飞前夕見られたと同 じ $\mathrm{pH}$ の極小層が完成し又それは酸素合量飞就ても極小層となつたのであ る。かくてての pH の異常分布は 31 日朝には再び解消したのである。

こいに見られた $\mathrm{pH}$ 逆轉層の出現は（1）從來報告されてみる $\mathrm{pH}$ 逆轉層 が數 $\mathrm{m}$ 或は數十 $\mathrm{m}$ の範圍に亘つて出現したのに對して數十 $\mathrm{cm}$ の狹い範 圍の內に發現するてと(2) 畫間に出現發澾した後夜間に消失すること(3) 酸 素量の甚だしい減少を件ふてと等の特徽を示す故, 著者は特に之に $\mathrm{pH}$ 逆轉 の小成層 (Dichotomous microstratification of $\mathrm{pH}$ ) の名稱を與へるるとと を提唱した。而して之が出現の原因火就ては關係湖沼因子中，水溫， $\mathrm{pH}$ 及 び酸索の三者のみの測定が行はれだをけなので沈定的に之を制斷するてとは 出來ない。併し湖沼に就ての科學常識に立脚して之を次の如く想像した。

師ちての $\mathrm{pH}$ 逆轉極小成廨の出現の先行條件として問題の水層に何物か酸

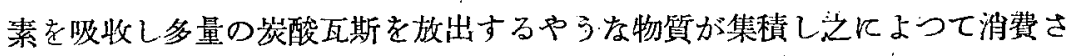
れる酸素量が,'同時にての水層中行行礼る炭素同化作用汇よて生亦方酸 索の生成量を遙かに淩ぎ差引酸素量の減少を招來すると共に又之に占つて生 する炭酸量は炭索同化作用によつて消費される炭酸量を凌鴐して小炭酸量 の增加を，文從つて $\mathrm{pH}$ の減少を喚び起したものである。。

かくて生じを $\mathrm{pH}$ 及び酸素の垂直的變化は夜間の冷却による上下水の混合. によつて解消し翋日再び墨間の溫度上景に件つて上下水の混合が困難と度る に及び上述の機構によつてその出現をくり返すものである。 下に述べるのは其後ての現象に就て行つた研究の結果である。

\section{本現象の頻出度}

本現象は湖沼の問題として重要なる澺味を有するか否かは第一龙それが蹎 
繁に出現するものなるか否かといふ事關係する。若しそれが極めて假然な

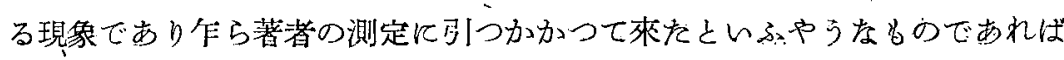

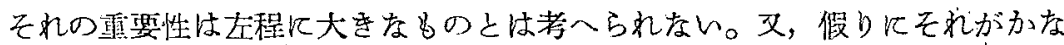
り頻繁に出現するものであるとしを場合には，との出現が年中時を定めずし て生起するものなるか或は特に准々出現する時があるものか，之亦ての現

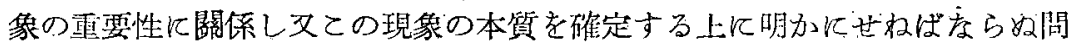
題である。

之等の理由により著者は引續いて 1938 年 9 月以降测定を繰り返した。

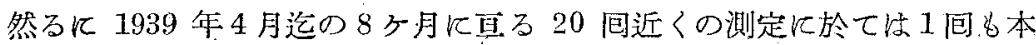
現象を見ることはなかつた。かくあることは著者の上の解釋よりす礼ば墕る 當然である。師ち上に述べをやうに本現象が出現するには夜間或程度の循環

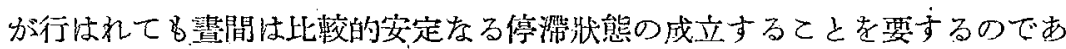
つて水の充分なる循環の行怯れる秋冬春の候に之が見られる己は豫期困蜼 のとてらであつたのである。忘に反してといに述べたやうな條件が晚春より 夏季の静䅼なる天候下になやすく調ふことは極めて可能のととに屬するので ある。

果して水の停帮の始つた 5 月 7 日となるや0.30-2.00 P.M. 間に行つた 测定で $0.8 \mathrm{~m}$ 霄と $1.3 \mathrm{~m}$ 層とで $\mathrm{pH}$ がそれどれ 7.2 及び 7.1 を示したのに 對して中間の $1.0 \mathrm{~m}$ では 6.9 を示し明かなる $\mathrm{pH}$ 逆缹の小成曆が發現した

第 2 表 (A) [1939 年 5 月 7 日]

\begin{tabular}{|c|c|c|c|c|c|c|c|c|c|}
\hline & \multicolumn{3}{|c|}{ 5.55-7.55A.M. } & \multicolumn{3}{|c|}{$0.30-2.00$ P.M. } & \multicolumn{3}{|c|}{$4.00-5.45$ P.M. } \\
\hline $\begin{array}{l}\text { Depth } \\
\text { m. }\end{array}$ & $\underset{\mathbf{C}}{\operatorname{Tem}}$ & $\mathrm{pH}$ & $\begin{array}{l}\text { Oxygen } \\
\text { (c.c./l.) }\end{array}$ & Temp. & $\mathrm{pH}$ & $\begin{array}{l}\text { Oxygen } \\
\text { (c.c./l.) }\end{array}$ & Temp..' & $\mathrm{pH}$ & $\begin{array}{l}\text { Oxygen } \\
\text { (c.c./l.) }\end{array}$ \\
\hline 0 & 20.55 & 7.2 & 5.68 & $20.55^{\circ}$ & 7.1 & 538 & 20.60 & 7.3 & 6.00 \\
\hline 0.5 & & 7.1 & 5.42 & & 7.2 & 5.56 & & $73^{r}$ & 5.74 \\
\hline 0.8 & & 7.1 & & & 7.2 & 5.57 & & 7.3 & 5.90 \\
\hline 1.0 & 20.50 & 7.1 & 5.37 & 20.50 & 6.9 & 5.50 & 2).60 & 7.3 & 5.94 \\
\hline 1.3 & & 7.1 & 5.12 & & 7.1 & 5.30 & & 7.2 & 5.90 \\
\hline 1.5 & 18.80 & 7.0 & 4.96 & & 7.0 & 4.78 & & 7.1 & 5.41 \\
\hline
\end{tabular}


- (第 2 春參照)。

但しこの時の逆轉は同じ日の夕方の測定に於ては $0.8 \mathrm{~m} の \mathrm{pH} 7.3,1.0 \mathrm{~m}$ の $\mathrm{pH} 7.3 ; 1.3 \mathrm{~m}$ の $\mathrm{pH} 7.2$ となつて既に消隇したのである。。

且つ又との時の测定に於て注目すべきは $\mathrm{pH}$ の極小膡の $1.0 \mathrm{~m} て ゙$ 惊 $\mathrm{pH}$ が朝の值 7.1 から㬩の

間 6.9 亿減少してるな

がら酸素赎朝の值 5.37

e.c./1 より書の值 5.50

e.e./l. 一㴰しておねて

とである。

てれは明か次先き

著者の觀测飞當り $\mathrm{pH}$

の減少之酸萦の減少々

が㴊行した事實之哴ひ

違つておるのである。

この點に就て疲再び後

に論及する筫である。

續いて微弱な $\mathrm{pH} の$

逆轉は 5 月 29 日比

筑 2 表 (B) [1929 年5月29日了

\begin{tabular}{|c|c|c|c|c|c|c|}
\hline \multirow[b]{2}{*}{$\begin{array}{c}\text { Depth } \\
\text { m. }\end{array}$} & \multicolumn{3}{|c|}{ I1.40 A.M,-2.15 P.M. } & \multicolumn{3}{|c|}{ 4.50-6.15 P.M. } \\
\hline & $\underset{{ }^{\circ} \mathrm{C}}{\operatorname{Temp} .}$ & pH & $\begin{array}{l}\text { Oxygen } \\
\text { (c.c./l.) }\end{array}$ & $\underset{{ }^{\circ} \mathrm{C}}{\operatorname{Tem}}$ & $\mathrm{pH}$ & $\begin{array}{l}\text { Oxygen } \\
\text { (c.c./l.) }\end{array}$ \\
\hline 0 & 20.8 & 77 & 6.98 & 20.6 & 7.7 & 7.14 \\
\hline 0.5 & & 7.6 & 696 & & 7.8 & 7.18 \\
\hline 0.7 & & 7.5 & 6.92 & & 7.8 & 7.16 \\
\hline 0.8 & & 7.7 & 6.78 & & 7.7 & \\
\hline 1.0 & 20.45 & 7.7 & 7.06 & 20.4 & 7.7 & 7.07 \\
\hline 1.3 & $"$ & 7.5 & & $\cdot$ & 7.7 & \\
\hline 1.5 & 20.15 & 7.5 & 6.71 & 20.25 & 7.6 & 6.95 \\
\hline 1.75 & & 7.5 & 6.78 & & 7.5 & 6.86 \\
\hline 2.0 & 19.6 & 7.4 & 6.94 & 20.0 & 7.5 & 7.11 \\
\hline 2.25 & & 7.4 & 6.82. & & 7.5 & 7.06 \\
\hline 2.5 & 19.15 & 7.2 & 5.70 & 19.05 & 7.3 & 6.71 \\
\hline 2.75 & & 7.1 & 5.17 & & 7.1 & 5.62 \\
\hline 3.0 & 18.25 & 6.7 & $4 . \dot{3}$ & 18.2 & 6.9 & 4.17 \\
\hline 3.25 & & 9.7 & 3.86 & & 6.7 & $3.6 t$ \\
\hline
\end{tabular}

見られた。

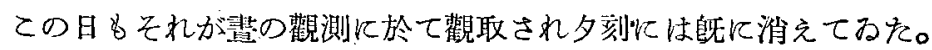

概してての頃に出現した当のは未だ充分に强力でなく早く解消するものの やうである。

かくて7月に入りその14日上り17日に互り連日觀測を行つねがその內， 裴水層の测定を行はをかつを15 日を除尗，每日本現象の出現を見るとるを 得を(第 3 表參照)。觀测の缺けた15 日に出現を見をと之は殆ど疑の餘 地のないととろである。

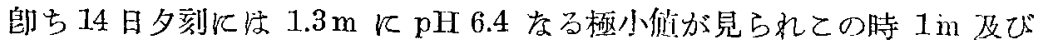


捁 $3^{\circ}$ 表

\begin{tabular}{|c|c|c|c|c|c|c|c|c|c|c|c|c|c|c|}
\hline \multirow{2}{*}{\multicolumn{3}{|c|}{$\frac{\text { July } 14,1939}{2.55-7.00 \text { P.M. }}$}} & \multirow{2}{*}{\multicolumn{4}{|c|}{ July 16,1939}} & \multicolumn{8}{|c|}{ - July 17, 1939} \\
\hline & & & & & & & \multicolumn{4}{|c|}{ 4.55-7.50 A.M. } & \multicolumn{4}{|c|}{ 3.30-5.55 P.M. } \\
\hline $\begin{array}{c}\text { Depth } \\
\text { m. }\end{array}$ & $\mathrm{pH}$ & $\begin{array}{l}\text { Oxygen } \\
\text { (c.c.ll.) }\end{array}$ & $\underset{{ }^{\circ} \mathrm{C}}{\operatorname{Temp}}$ & $\mathrm{pH}$ & $\begin{array}{r}\text { Oxygen } \\
\text { (c.c./l.) }\end{array}$ & $\begin{array}{l}\text { Total. } \\
\text { carbon } \\
\text { dioxide } \\
\text { (c.c.ll.) }\end{array}$ & $\underset{{ }^{\circ} \mathrm{C}}{\text { Temp. }}$ & $\mathrm{pH}$ & $\begin{array}{c}\text { Oxygen } \\
\text { (c.c./l.) }\end{array}$ & $\begin{array}{l}\text { Total } \\
\text { cardon } \\
\text { dioxide } \\
\text { (c.c./l.) }\end{array}$ & $\underset{{ }^{\circ} \mathrm{C}}{\text { Temp. }}$ & $\mathrm{pH}$ & $\begin{array}{l}\text { Oxygen } \\
\text { (c.c./l.) }\end{array}$ & $\begin{array}{l}\text { Total } \\
\text { carbon } \\
\text { dioxide } \\
\text { (c.c./l.) } \\
\end{array}$ \\
\hline 0 & 7.3 & ' 6.12 & 32.7 & 7.2 & 5.27 & 11.3 & 30.0 & 7.0 & 5.22 & 11.5 & 32.4 & 7.2 & 5.77 & 10.7 \\
\hline 0.5 & 7.4 & 6.03 & & 7.1 & 5.88 & 10.9 & & 6.9 & 5.24 & 11.7 & & 7.3 & 5.82 & 10.7 \\
\hline 0.8 & 7.3 & 6.24 & & 6.8 & & & & & & & & 7.8 & 6.42 & \\
\hline 1.0 & 6.7 & 5.56 & 29.9 & 6.8 & 5.42 & 11.4 & 29.8 & 6.9 & 5.20 & 11.8 & 30.4 & 6.7 & 5.51 & 11.9 \\
\hline 1.3 & 6.4 & 3.70 & & 7.0 & & & . & & & & ? & & & \\
\hline 1.5 & 7.2 & 6.60 & 289 & 7.1 & 6.50 & 10.9 & .28 .8 & 6.9 & 5.21 & 11.8 & 29.2 & 7.5 & 7.46 & 10.8 \\
\hline 1.8 & 7.3 & .7 .08 & & 7.3 & 7.06 & & & & $\cdot$ & & & & & \\
\hline 2.0 & 7.4 & 7.31 & 26.3 & 7.3 & 7.52 & 11.2 & 26.4 & 7.0 & 6.62 . & 11.8 & 26.8 & 7.4 & 7.52 & 11.0 \\
\hline 2.25 & 7.3 & 6.79 & & & & & & & & & & & & \\
\hline 2.5 & 6.7 & 5.10 & 24.8 & 6.8 & 5.73 & 13.0 & 24.6 & 7.1 & 6.70 & 12.5 & & 6.9 & 5.81 & 12.7 \\
\hline
\end{tabular}


$1.5 \mathrm{~m}$ 層の酸素量が火火 5.56 c.c./1 及び 6.60 c.c./1 なるに $1.3 \mathrm{~m}$ は 3.70 c.c./1 とレふ小さな做を示した。

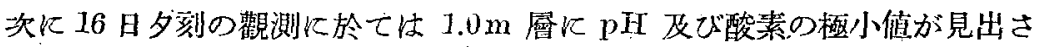

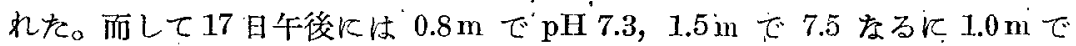
pH' 6.7 を示し酸素量が文ての畨に於て最小做を示した。

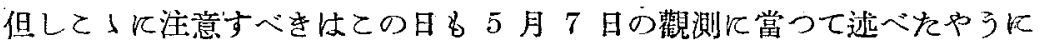
酸素量を同じ水磨の朝の量に比較すると他の磨に於けるが如く酸索量が管加 してるることが見られるのである。唯他層と異るのはその墑しすが他層に比 して著しくない點である。

8月床觀測出來なかつたが恐らく可續いて本現象の出現に適當な湖沼因 子の組合せが持續し度々その現象が現はれそものと制斷される。

9 月に入つて後試みを觀測には未だ一四も本現象を見ない。

以上の觀測の結果を要約するに

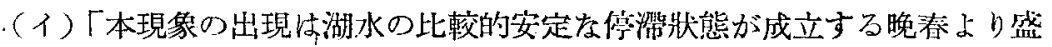
夏に瓦つて頻繁に行はれる!。乙れは上述の著者の本現象出現の原因に對す る推测と矛盾しない。

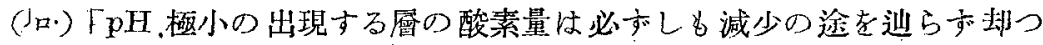

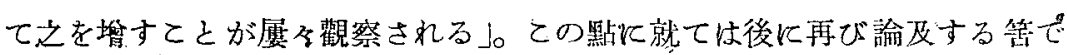
ある。

\section{浮游物の分布との關係の顯微鏡的研究}

著者は本現象發現の原因として問題の水層中に酸素を吸收し多量の炭酸瓦 斯を放出するやうな物質が集積するととを想像したが進んでその物質が如何 なる多のであるかに就ては敢て之を述べやうとはしなかつた。

但し之恃述べるととを控へただけであつて著者自身はそれが水中に生產さ れたプランクトン等の遺䯓或はその斷片又は之に由來する分解车成物であつ てそれが腐敗或は之に類した分解的變化を行ふ当のであらうと想像して居た のである。

假にとの著者の想像が嘗つてるをとして，且つ又その分解を蒙るものが顯 


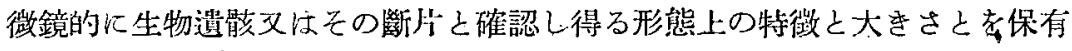
してるるやうな場合には本現象の出現時に各水畨中の浮游物を探集して顯微

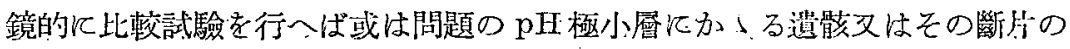
著しい集積を確認し得て上述の著者の想像を裹書する論據となるであらうこ とが考へられるのである。

浮游物の垂直分布の矮微鏡的研究を企てた第一の理由がこ〉にある。 : 更に又次のやうなととも考へられない譯でない。郎ち著者の考へを酸素を 消費し炭酸瓦斯を出す物質といふのが實は動物性プランクトンであつて或る 種の動物性プランクトンが水溫度，照度等の條件に制縛されて問題の水

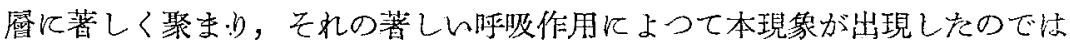
ないかと考人られ如譯ではない。然りをすればての場合には文浮游物の調 查によつて動物性プランクトンが特に數多く問題の水層に集積してみるとと を證明し得る篦である。

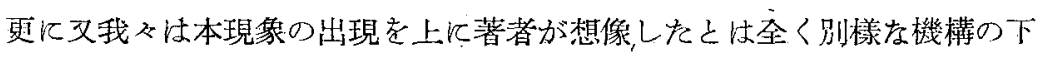
に招來されたものと想像するととも許され就譯ではない。

師ち以上の著者の考へでは特定水層に酸素省消費し多量の炭酸瓦斯を放出 するタのの集積を想像しえのである。之之反對飞之の特定水層沉於て炭酸瓦 斯を消費し酸素を放出する多の，即ち植物性プランクトンの或物の密度が他

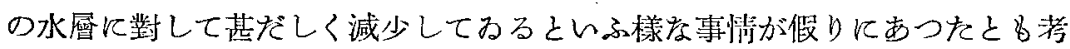

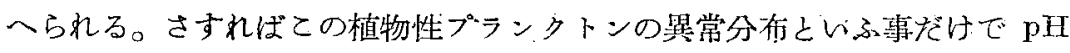
及び酸素量の減少曆の出現が可能になる譯である。．

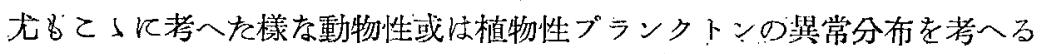

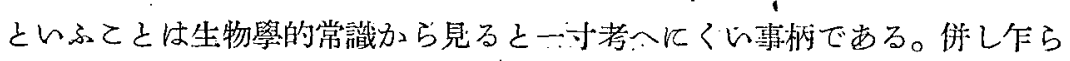

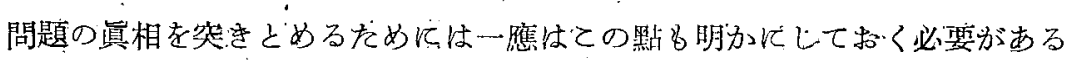
のであつた。

鬼桷以上二つの理由から著者は問題の小成曆が充分飞撥現した 7 月 14 日の夕之同月 17 日の夕の觀测飞當つて各水層上りの採水飞就て浮游物の垂 直分布を檢した次第流ある。 
計测方法及び其結果に就ての細が點は別に報告の機會があらうと考へる ので，こっには當面の問題に關聯した部分を中心としてその大要をのべるに 止める。計測飞當つては各水層より探つた 50 c.e. の試水に 5 c.e. のフォルマ リンを加八保存しをものをよくく振りまぜ，ピペットを以てその約 5 c.c. 索

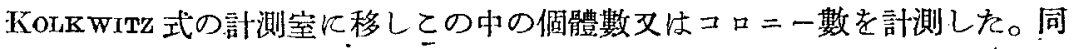
一の試水に就ては 3 包或は 4 包計測を繰り返し，得られた做の本均值を求め た。而がしてか小る計测を 7 月 14 日の分に於ては $0 \mathrm{~m}$ より $4.5 \mathrm{~m}$ 荙 14 種

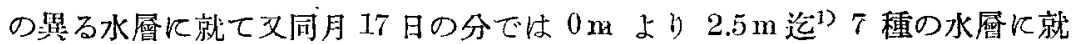

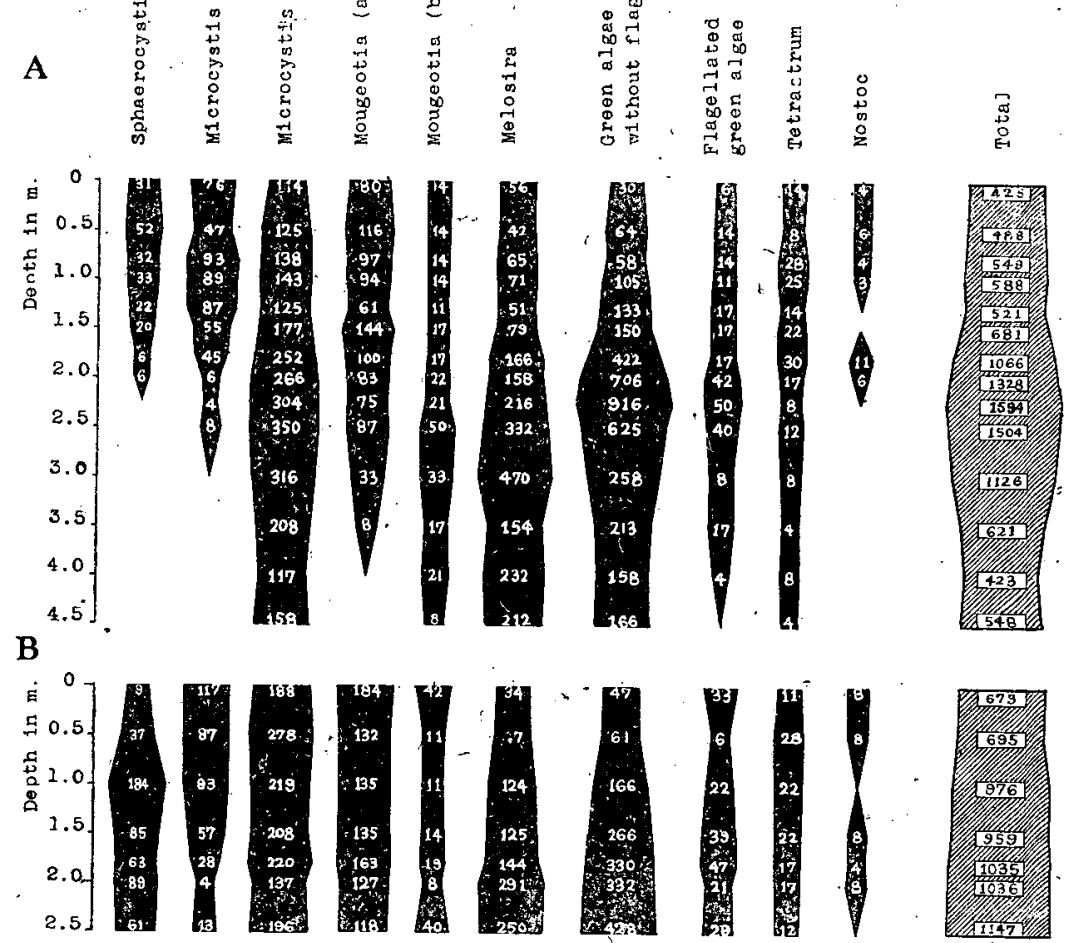

第 2 圆 䯩須賀沼に於ける植物性プランタトン心深さに上る分布. A， 1939 年 7 月 14 日 (2.55-5.00.P.M.). B, 1939 年7. 月 17 日 (3.30-5 55 P.M.). 數字は 1 c.c. 中の個體數或はコロニー數を示す。

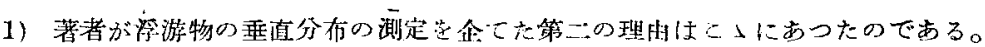


て言みた。第 2 圖は計測されたプラントンの中主要なるものの個體數及び ロニ一數を示したもので其の數は試水 1 c.e. 亿就ての值である。

此の圖より第一飞觀取されることは揭げられたプランクトンが何れ多植物 性のものであることと，その何れの種類も pH極小層（7月 14 日に於ては

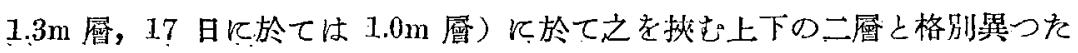
分布狀態を示さないといふととである。

尤も仔細にみる゙時は 14 日の 1.3 m 層では Mongeotia (a), Mougeotia (b), Melosira, Tetrastrum, Nostoc, Microcystis (b).の值が $1.0 \mathrm{~m}$ 及び $1.5 \mathrm{~m}$ 懕の

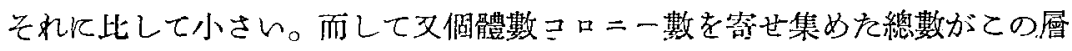
で極小示してるる。かやうな閏係が果して偶然の8のであらうか，と礼と も文それが閣題の $\mathrm{pH}$ 極小角の出現と何等かの因果關係にあるものであらう かに就ては倠今の之ころ判断の下しやうがない。

或は問題の水層の pHが少くなつたととが或は酸素量が之を扷を上下の水

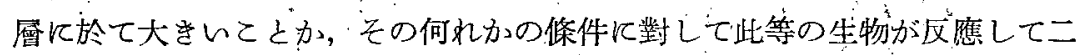
次的にての水層を避けて $\mathrm{pH}$ の大なる或酸素量の大をな水膚八逃避すると 云つたととが起つたためと考へられ如譯で是ない。

それは鬼に角としてとのプランクトンの分布の䔬常さの程度は沟に小さい ๖のである。之を侗體數，コロニー數の總計と就て見るに問題の水層と之を

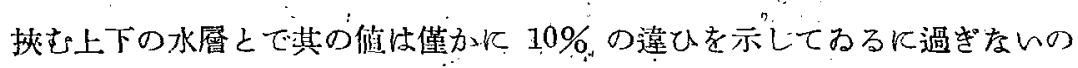
である。

一方之を觀測されを $\mathrm{pH}$ なり酸素量なりの等水腐間に見られる相違の大 きさに比較するときす゚ラシクトン總數に於ける $10 \%$ の相違壮之等 $\mathrm{pH}$ ，酸

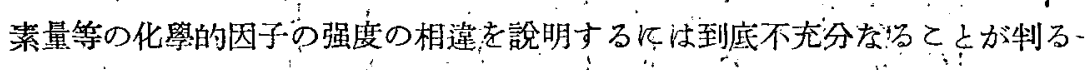
のである。

之を要するに植物性プランクトンの分布は少くとも本現象出現の主要原因 の內には數へられないといふ結論を得るのです。

次に述ぶベさは動物性プランクトンの問題である。動物性プランタトンの 分布が本現象之直接閶係のないてとは下下速べるやうに牛理論的に之を論斷 
するととが出來る。

A. P. StcherBaKow (2) によれば Diaptomuls gracilloides の䧳の一尾が $5^{\circ} \mathrm{C}$ で 24 時閒に吸收する酸素量は $0.001 \mathrm{mg}$ であり，その雄或は Cyclops lenckartii 及撓脚類のナウプリウスの吸收量は更に小さい。

: 今との吸收量が通常の化學反應の溫度係數を以て温度の上早と共に增加す るものとすれば $30^{\circ} \mathrm{C}$ (測定當時の高須賀沼の水溫) 近くでは $0.008 \mathrm{mg}$ 位に なると拷へられる。:

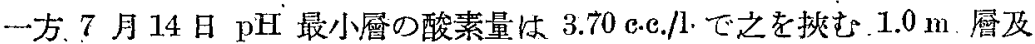
び $1.5 \mathrm{~m}$ 層の酸素量は 5.56 c.e./1 及び 6.60 c.c./1 であつた。今同日朝ての各 水曆が略同じ酸素量より出立しをととは疑ひない。然りとすれば $\mathrm{pH}$ 最小曆 では朝からこの测定時迄の間の 10 時間近くの間に $1.0 \mathrm{~m}$ 厤に對しては 1.74 c.c./l 及 $1.5 \mathrm{~m}$ 層に對しては 2.90 c.c./ 1 からの餘計の酸素の消失があつた譯 である。之が上に考へを如き動物性プランクトンに低て行はれをものとする ときそれが $1 l$ に就き何尾位のプランクトン個體によつて顯現されるが上 の Diaptomus の值より推算する事が出來る。

$30^{\circ} \mathrm{C}$ で 24 時間に 1 個體の酸素消費量が $0.008 \mathrm{mg}$ (體皘にして之は $4 \times 10^{-3}$ c.c. 從て 12 時間で $2 \times 10^{-3}$ c.c.) 從て上の 1.74 c.c. 或は 2.90 e.e. の消費に は 900 1500 個體の Diaptomus 或は之と大きさを近くする動物性プランク トンを洞想しなくてはならない。

之を換言すれば問題の現象發現の原因が動物性プランクトンの集樍による

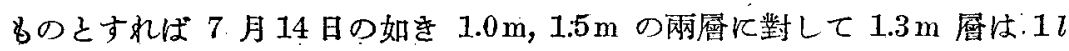
につき900〜1500 尾からも餘計の動物性プランクトンの集積が見られねば ならぬ事になる。か小る數字壮事實と隔るとと著しきものがある。

著者の測定の場合の如き各尿と8 200-300 c.c. の探水に當つて其中に混 んじて來るからる動物性プランクトンは 3 匹或は 4 匹といふのが通常で, 1 匹も見出されぬ場合も珍しく教と云ふ有樣である。

かくしてみれば第二の疑問に對しては「動物性プランクトンの分布も亦問 題の $\mathrm{pH}$ 極小愿の出現の少くとも直接の原因ではない」と云ひ得る次第で 
ある。

以上によつて問題の現象と動物性或は植物性プランクトンの分瓜をが直接 の因果閶係によつて結びついで居ないととが制明した。殘る壮浮游物分布の゙ 測定を企圖した第一の點であうて，問題の水糜にプランクトンの遺䯓或はそ の顯微鏡的に確認し得る斷师が特に著しく集積するのが見られるか否かの問 題である。この問題は著者が特に之を明確に解炕したいと乔然して來た\&の であり，且又上の植物性プランクトン計測に當つて䏭にとの點に注意して

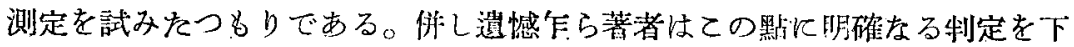
すに充分存結果に到達し得なかつた、

がくてこの問題に就ての解答としては

「浮游物の顯微鏡的計查は $\mathrm{pH}$ 極小層にプランクトンの遺骸或はその斷片 の浮游するbのが特に多いといふてとを積極的に示す結果に到達しなかつ を」といふ記述を行ふに止めるの外はない。

\section{本現象と水中の全炭酸量の變動}

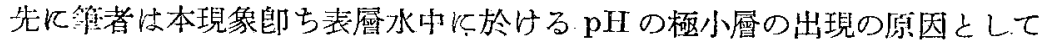
酸素を消損し炭酸瓦斯を多量に生成するものが集積し，その結果として pH の減少が見られる\&のと想像することを度々述べたがこの想傻は實際に测定

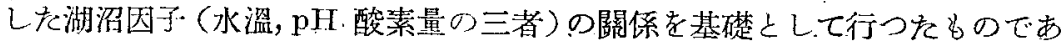
る。從てての想像を正當化するためには同時に炭酸量の變動量を實測して矛

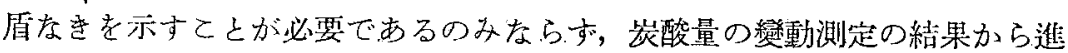
んでそとに䘕れる酸素代謝，㷋酸代謝の本質を探方齐望母ある譯である。

然るに厥に䦗題になつたとと将酸菜の日中變化量から推して炭酸の日中變 化量が恐らく Il K就て 0.1c.e. 而至數 e.e.の安のであらうととが想像され るととである。而して以下にのべる議論を正當に進めんがをめには炭酸量を $1 l$ 亿つき少く 801 c.c. 迄正しく测り得るが如き测定法の存在するととを

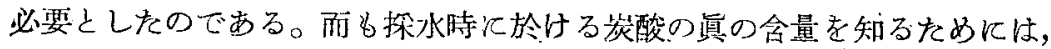
その時の含有舞酸を直ちに固定して後に测定するか探水後數分の間にその测 定を行ふてとが必要である。 
從來考案された多數の宸酸或㹥全炭酸の測定法は之をその精度の一面から のみ見をぞけでも，一のとして著者の上述の希筀を充たすものはないのであ る。師ちそれらの力法には水 $1 l$ 飞就てその含量炭酸量を $0.1 \mathrm{e}, \mathrm{e}$ ，迄の精度 を以て與へるものは一つもないのである。

ての故に著者はその齐望する條件を具へを分析法の案出を企て別に報告す る水中の全炭酸の新测定法(日本化學會邦文又は歐文會誌儿近く發表の豫定) ○案出江成功七，之を用ひて 7 月 16-17 日に直つての測定に於て全炭酸を 同時に測定した。その結果を次に論考するととにした。

先づ第一に注目されることは 17 日朝の全炭酸量が表噼 $0 \mathrm{~m}$ 上り $2.0 \mathrm{~m}$ 迄 殆ど一样に分布する.ととですつて之は $0 \mathrm{~m}$ より $1.5 \mathrm{~m}$ 迄の酸素の一樣店る分

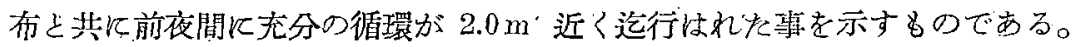
然るにこの一樣垔素友び全炭酸の分布は夕副迄の間に各層間に著しい變動 を示し特飞至炭酸は $0,0.5,1.5$ 及び $2: 0 \mathrm{in}$ 亿於て何れも明かなる減少を示し それらに相虽する $\mathrm{pH}$ の䁌加に對應して居る。而して獨り $1.0 \mathrm{~m}$ のみは $\mathrm{pH}$ の減少が見られそれが㑑加乍ら全笼酸の增加之對應してるるものである。

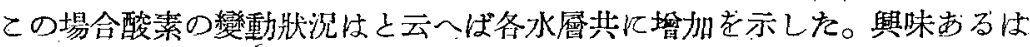
$\mathrm{pH}$ 減少の見られた $1.0 \mathrm{~m}$ 層飞於て前年の觀察とは相反し 5 月 7 日の觀察 に於けると同じく少量乍らその增加を示しておる事である。

之を以て見虬ば $\mathrm{pH}$ の變動の方向古直接酸素變動の方向によ゙つて決定され るものでちく水中全装酸の變動の方向によのて決定されるものであるてとが 判るのである。

尤多 pH を左右するものが獨り全炭酸量の變動量にあるかそれと发炭酸の

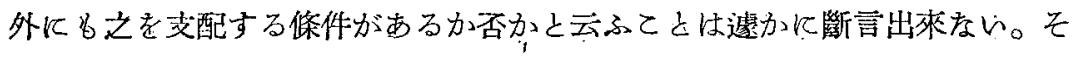
れ炕しても $\mathrm{pH}$ を左右する要因中の最大なるものが㞸酸であらうととは殆に゙ 疑ふ餘地のない所である。”

との點は $\mathrm{pH}$ 價と全卦酸量之過剩監基量之の 17 日朝に於ける相互閣係汃 らも充分察知される（第 4 表參照）。乙の時 $0 \mathrm{~m}$ 之 $0.5 \mathrm{~m}$ 亿於ける $1 . l$ 中の 渦剩醓基當量は $0 \mathrm{~m}$ が 0.000014 丈け大きいが全岑酸の當量は $0.5 \mathrm{~m}$ の方 
0.0002 文大き〈差引 第 4 表

き重炭酸覧として過 1939 年 7 . 月 17 日 $4.55-7.50$ A.M.

剩監基之結合し得ざ。

る炭酸量は $0 \mathrm{~m} \mathrm{~V}$ 班して $0.5 \mathrm{~m}$ では 0.00003 掌量丈大き いととに存りをに應 じて $0 \mathrm{~m}$ の $\mathrm{pH} 7.0$ に對して $0.5 \mathrm{~m}$ 壮 6.9

\begin{tabular}{|c|c|c|c|}
\hline $\begin{array}{c}\text { Depth } \\
\text { m. }\end{array}$ & $\mathrm{pH}$ & $\begin{array}{c}\text { Equivalent } \\
\text { of total } \\
\text { carbon dioxide } / l \text {. }\end{array}$ & $\begin{array}{c}\text { Equivalent } \\
\text { of } \\
\text { excess base } / l .\end{array}$ \\
\hline 0 & 7.0 & 0.00102 & 0.000451 \\
\hline 0.5 & 6.9 & 0.00104 & 0.000437 \\
\hline 1.0 & 6.9 & 0.00106 & 0.000472 \\
\hline 1.5 & 6.9 & 0.00106 & 0.000458 \\
\hline 2.0 & 7.0 & 0.00105 & 0.000478 \\
\hline 2.5 & 7.1 & 0.00112 & 0.000670 \\
\hline
\end{tabular}

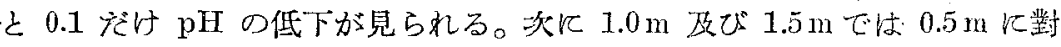
して炭酸の堂量が何れも 0.00002 丈增してねるが過剩監基は夫れ夫れ0.00003

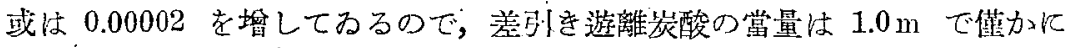
0.00001 嫦量を堆し $1.5 \mathrm{~m}$ では全く堽減なきため $\mathrm{pH}$ \& $0.5 \mathrm{~m}$ と變りをく 6.9 を示ずののやうである。更に $2.0 \mathrm{~m}$ では $1.5 \mathrm{~m}$ に對して炭酸の虽量に 於て 0.00001 を減じ過剩監基當量に於て 0.00002 を增し從つて遊離岑酸の 當量は 0.0003 そ゚け減ずること $0.5 \mathrm{~m}$ に對する $0 \mathrm{~m}$ の關係に見るが如く,從 つて又.0m と同じく $\mathrm{pH} 7.0$ を示すやうに見える2)。

以上の如き相閣閣係が見られることは之等の水層に於ける $\mathrm{pH}$ が少くとも 大部分含有される過剩覽基當量と全炭酸當量によつて決定されるものである と考へられる。さうして洞剩監基當量の如きは比較的短時間中に著しく變動 する筈はなんのであるから結局吾等が見る $\mathrm{pH}$ の日中變化忙之をこの炭酸の 變動に大體歸して差考入なからうと思ふのである。

かくして見れば問題の pH極小愿の出現の原因が酸素を消費し多量の㷋酸 を生成する何者かの集積にあらうとの著者の推宗はとの點から女支持される ஆのと云つてよからう。

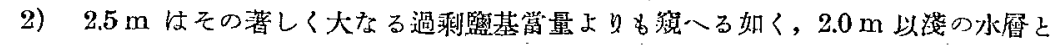

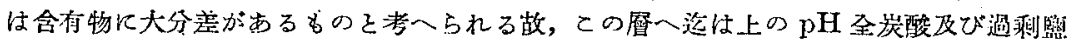
基當量の相關關係の数量的考察を避めることは蜜る避くべをものと思ふ。 
次に著者はての炭酸生成の機構に就ての詇考を試みれいと思ふ。

之に先立つて著者法湖水水中に於て。. 場合として考へ得られる限りをすげて下に示すことにした。，

(A) 酸素の生成 炭素同化作用

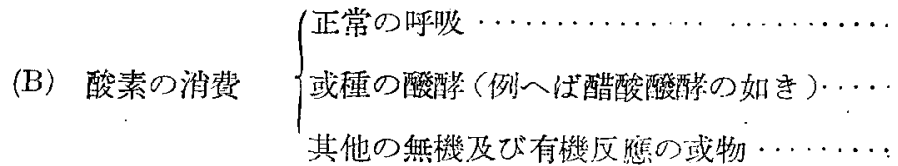

(C) 炭酸の生成 $\int(2)(3)$ 其他の唒瞵

壣にあげを諸種の反應炕就て下の著者の議論に最も大きな關係のあるのは

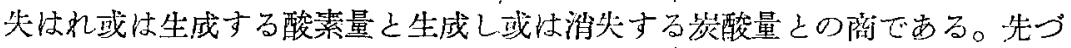

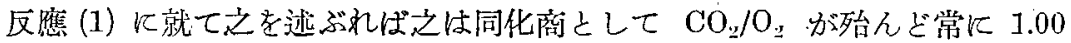
或は之に近いものであり，それは WILLSTÄTTER (1918) 以來諸芜の研究によ り反復證明されてるるとてろである。

次飞正常の呼吸 (2) に於て $\mathrm{CO}_{2} / \mathrm{O}_{2}$ は常飞 1 よりは小さく $0.7 \sim 1.0$ の間 を彷得する。乙れ名普く知和を事實である。又醌酸酸醋を以て代表される型 式 (3) の反應で壮少量の酸素の消費の下に大量の炭酸が生成する。故にそ の $\mathrm{CO} . / \mathrm{O}_{2}$ 恃當然 1 より大をくなり例へば

$$
\mathrm{CH}_{3} \cdot \mathrm{CO} \cdot \mathrm{COOH}+\frac{1}{2} \dot{\mathrm{O}}_{2} \rightarrow \mathrm{CH}_{3} \mathrm{COOH}+\mathrm{CO}_{2}
$$

(焦性蒲苟酸)

(醋酸)

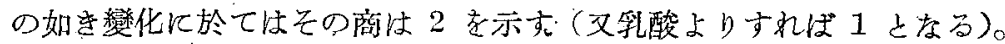

(4)の型式に屬する反應の一つとして牧二價の鐵化合物が水中の酸素によ

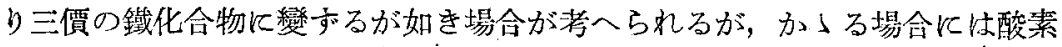
の沙費飞對して炭酸の生成が排は亦從て $\mathrm{CO}_{2} / \mathrm{O}_{2}$ は 0 となる。

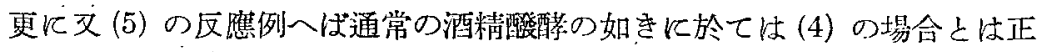
反對飞炭酸の生成を見孛がら酸素の消失を見永 $\mathrm{CO}_{2} / \mathrm{O}_{2}$ は無限大となる。

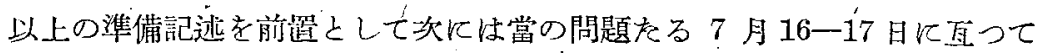
の酸素變動量と炭酸の變動量との關係を洘察して見るととにする。 
第一に若察したんのは夜間に於ける湖水中の $\mathrm{CO}_{z} / \mathrm{O}_{2}$ である。

著者は夜間に於ける水の循環混合の限界を $2.75 \mathrm{~m}$ と見做し（14-15日に 瓦る水溫測定 14-17 日に亘る酸素の测定結果からかく判斷するととが許さ． れると信市る $\left.{ }^{3}\right), 0 \mathrm{~m}$ より $2.75 \mathrm{~m}$ に互る底面積 $100 \mathrm{~cm}^{2}$ の水杜を想像しこ の中に溶在する酸素量孝り装酸量を次の如くに見積つた（第 3 圖參监）。

即ちての水桂を表面が $0.25,0.75,1.25,1.75,2.25 \mathrm{~m}$ で切斷し 6 䇢の圓 盤を作り各圓盤はそれぞれ $0,0.5,1.0,1.5,2.0,2.5 \mathrm{~m}$ に於ける採水に就て 定められを酸菜量又は全炭酸量と同じ割合の酸素又は全炭酸を以て夫れ夫れ 一樣に充されてるるとする。次に之等の酸素なり炭酸なりの總和を求めれば 之はこの水杜中に含まれた全體の酸寀量或は炭酸量になる譯である。之等を $\Sigma \mathrm{O}_{2}$ 及文び $\Sigma \mathrm{CO}_{2}$ で表はすととにする。すると $\Sigma \mathrm{O}_{2}$ 怄 16 日多には 168.43 c.e. 17 日朝には 157.9 c.c.寺示し $\sum \mathrm{CO}_{2}$ は 16 日夕. 315,25 c.c. 17 日朝 326.75 c.c.を示す。そてで 17 日朝の $\Sigma \mathrm{O}_{2}$ 及び $\Sigma \mathrm{CO}_{2}$ と 16 日夕のそれらとの 差を求め之を $\Delta \Sigma \mathrm{O}_{2}$ 及び $\Delta \sum \mathrm{CO}_{2}$ で表はせばそれらはー10.52 c.c. 及び +11.50 c.c. と存る。

ところが上に推定しをところより $2.75 \mathrm{~m}$ 以深の水屡とこの水桂との間に は酸素なり炭酸考りの交換はなかつた多のと考へるてとが出來る。文外氯と

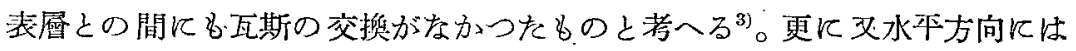
無諭之等の物質の濃度は殆んど變化なしと考へてょいのであるからての水柱

3）假にそれらの場所で瓦斯の交换が行はれたとしても，その方向はつなで著者の 議論を肯定するやうなるのでこそあれ決しでえの矛盾によるるのでないてとは次に記す

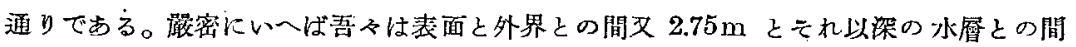
の瓦斯交換を無視してばならない。掌時の $0 \mathrm{~m}$ の酸素量は 110\% 以上の過能和の狀態

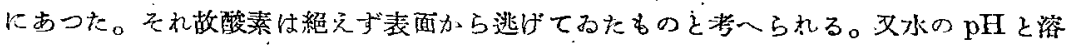

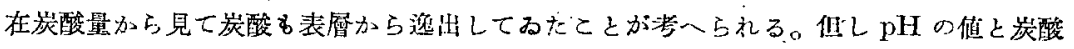

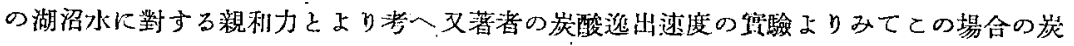
酸の逸出速度は酸素の魀出速度に對して問題にならない。而してこの絬果は点の意味に 於ける $\Delta \Sigma \mathrm{CO}_{2} / \Delta \Sigma \mathrm{O}_{2}$ より惯測の $\Delta \Sigma \mathrm{CO}_{2} / \Delta \Sigma \mathrm{O}_{2}$ を小ならしをることになるのみであ

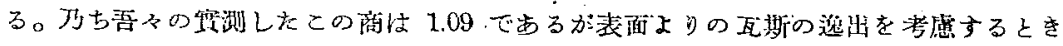

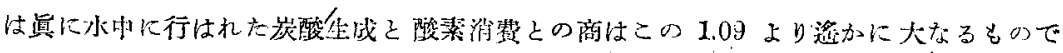


妁問題の期間中酸素炭酸に就ては一つの隔離物質柔 をなしてるをと見做すととを得るのである。して見

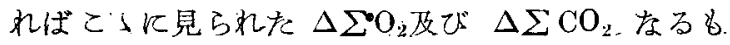
のは實際乙の水杜內で 16 日夕より 17 日朝迄の間飞 化學的或は生化學的變化火上つて头流れた全酸素 量を表はすものであり爻生成しを全炭酸量を表はす

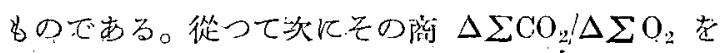
求むる時その值から吾々忙その間ての水中で行はれ を酸素炭酸代謝が如何をる性質のものであつそがを 制斷するととが出來る譯である。然らばその $\Delta \Sigma$ $\mathrm{CO}_{2} / \Delta \sum \mathrm{O}_{2}$ がごの場合如何なる做を示したかとい へば 1.09 になるのである。

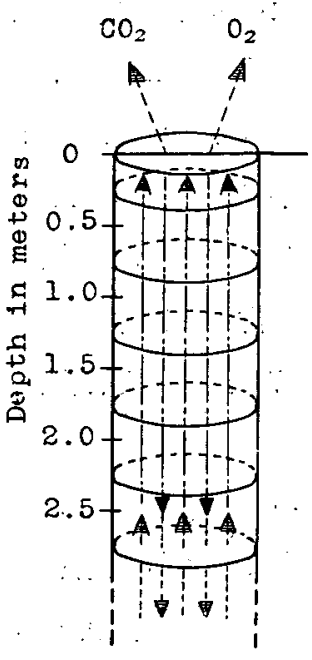

第 3 圖

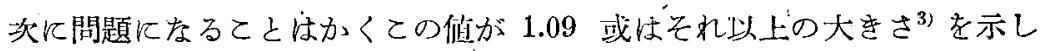
ておるの仗何故であるかといふととである。

之炕對する包签驻简單でする。消費した酸素の體棈に比して大量の炭酸を

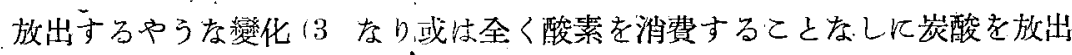

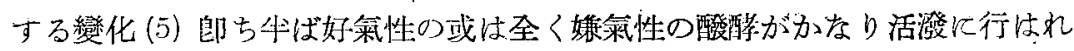
てみをと之を示するのである。勿論その外飞動物性或は植物性プランクトン 或は其他の湖沼生物による正常の乎吸が行はれ或程度迄炭酸の生成を件ふ酸

むつたららことが想像されるのである。

文 $2.75 \mathrm{~m}$ と以深の水層との間に混合があゔたとして假りに 16 日夕の $2.5 \mathrm{~m}$ 腐の水 が $3.0 \mathrm{~m}$ 層のそれを位朝迄に完全に混合したとする。 16 日夕 $2.5 \mathrm{~m}$ 層の酸素及び炭酸 量がそれぞれ 5.73 c.c./1 不び 12.7 c.c./1 であつたし又同じ特 $3.0 \mathrm{~m}$ 層では 15 日午後 子同㥞酸素 1.45 c.c.l 1 及び炭酸 17.4 c.c./1 であつたと見做せば完全混合によつて $2.5 \mathrm{~m}$

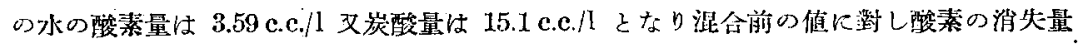

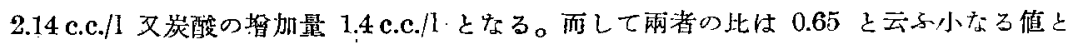
なる。そこでか」る混合が起ると云ふてとは上の $\Delta \sum \mathrm{CO}_{2} / \Delta \Sigma \mathrm{O}_{2}$ は 0.65 なる如焦 件があるにも拘らず 1.09 を與一ることを示するのであつて，從つてそれは県の意味の $\Delta \Sigma \mathrm{CO}_{2} / \Delta \Sigma \mathrm{O}_{2}$ が之刃 1.09 以上の值を示すべきであるとの結論て導くるのである。何

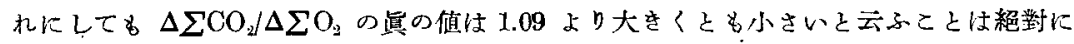
ないとをを示して居る。 


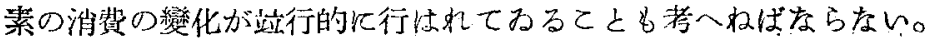

それ以上立ち大つての推論は避けるとして，ていには

$\lceil 7$ 月 16 日夕ー17 日朝迄 $0-2.5 \mathrm{~m}$. の水層中怄は正常の呼吸などと共に

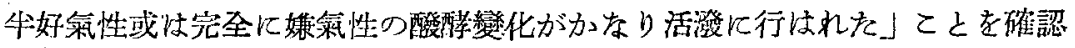
したことを述べるに止める。

做，つけ加ふべきはか」る酸酸變化は獨り夜間に留まら亦更に次にあぐる 17 日朝一17 日夕江互る書間にも繼續して行はれたととが疑ひないといふ事 である。

か小 る考慮の下㳄次は每間の

第 5 泰

$\Delta C O_{:} / \Delta O_{2}$ を檢討す方てとにし

よう。先づ注意すべはこの期閒 は外界よりの光，熱の浆射によつ て一般に水溫の上鼠が見方れ袁箇 程气の上吕度高く從つて夜間飞行 法れれ水の循環惊止し上下層の 混合が休止する。を的备水愿は それぞれ獨立の隔離物翼采と見な

(Morning-evening) July .17. 1939.

\begin{tabular}{l|c|c|c}
\hline $\begin{array}{c}\text { Depth } \\
\mathrm{m} .\end{array}$ & $\Delta \mathrm{O}_{2}$ & $\Delta \mathrm{CO}$, & $\frac{\Delta \mathrm{CO}=}{\Delta \mathrm{O}_{2}}$ \\
\hline 0 & +054 & -0.8 & 1.5 \\
0.5 & +0.85 & -1.0 & 1.2 \\
1.0 & +0.30 & +0.06 & $(0.2)$ \\
1.5 & +2.25 & -0.1 & 0.4 \\
2.0 & +0.90 & -0.8 & 0.9 \\
2.5 & -0.89 & +0.2 & 0.2
\end{tabular}

すととが出來るやうになる。從つて各水層に就ての $\Delta \mathrm{CO}_{2}, \Delta \mathrm{O}_{2}$ を定め $\Delta \mathrm{CO}_{2} / \Delta \mathrm{O}$ ，を定むればそれ㥀ちに當該水尿中に自られを酸素及び炭酸代 謝の冈容を示すもの上考へる事が出來る。

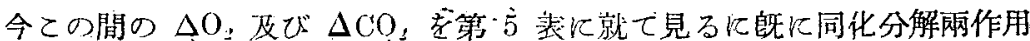
の對償深度 (Compensation depth) 以下飞位する $2.5 \mathrm{~m}$ を除き 0-2.0 $\mathrm{m}$ 迄 の冬層は例外なし炕朝から夕方にかけて酸素量の增加を示してるるので之等 の水層中では酸素消費の戀化飞對して同化作用が打ら腆つだけの活潑さを以 て行はれ壳ことが示される。之に應じて器酸量は減少してるる。但し $\mathrm{pH} の$

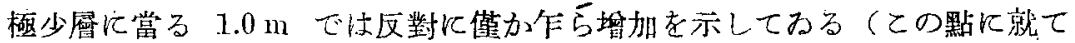
は後に再び論和ることにする。

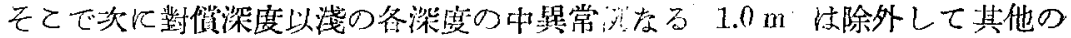




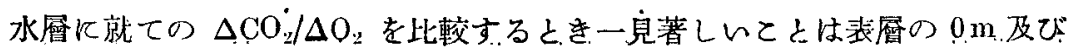
$0.5 \mathrm{~m}$ でばその㥀が，1.5 或は 1.2 で 1 より遥かに大きいてとであり又之に 反して $1.5 \mathrm{~m}$ 及び $2.0 \mathrm{~m}$ で柱その值が 0.4 或は 0.9 で1より小なるととで ある。且つその做が $0 \mathrm{~m}$ て最大て深度と共に值を減じ $1.5 \mathrm{~m}$ 層を極小とし て 2.0 mで再び增加してるるてとも注意に值する。

鬼角，かく、 $\Delta \mathrm{CO}_{2} / \Delta \mathrm{O}_{2}$ が深度によつて值を異にするてとは深度によつ て行はれる酸素炭酸代謝の各種行程が異ることを物語るものである。

㧫して今それらの行程を論考するに賞つて吾くは上に夜間の代謝行程に就 て得を知識を基礎として之を淮めることが出來る。唯夜間と異る點は夜間の 諸變化行程に加へて基間には炭素同化作用が之に介入する點でての因子が一 つ加はるだけ問題が椱雜化する理である。

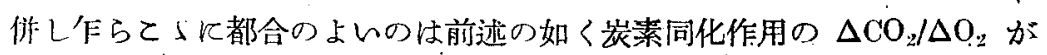
殆んど 1.0 に近いどとであつて, それは吾人の得を $\Delta \mathrm{CO}_{2} / \Delta \mathrm{O}_{2}$ の解釋を甚 ぞ采にしてくれるのである。

借て夜間の變化に就ては上飞「正常の呼吸 (2) の外比牛好氣性 (3) 或は全

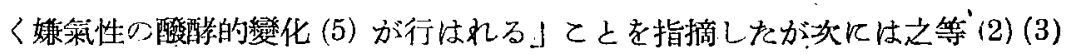
(5) の變化に炭素同化作用 (1) が組合さつた種々なる場合を考虑して $\Delta \mathrm{CO}_{2}$ / $\Delta \mathrm{O}_{7}$ の娔と結びつけて見るととにする。

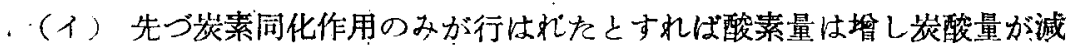
b) $\Delta \mathrm{CO}_{2} / \Delta \mathrm{O}_{2}$ は 1 になる。

（口）炭素同化作用之正常の呼吸のみが行はれるとし且つ前變化が後變化 を淩ぐ場合飞舟酸素量は增し炭酸量は減少し $\Delta \mathrm{CO}_{2} / \Delta \mathrm{O}_{2}$ ，は１以上となる。

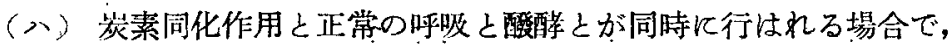

炭素同化作用が著しく活潑に行はれる時には酸素量を增し，又一般炕岸酸 量が減和る。但しての時呼吸と酸醇との强さに就て（甲）前者が强ければ $\Delta \mathrm{CO}_{2} / \Delta \mathrm{O}_{2}$ は.1 以上になるととあるへく(乙）後者が强ければ $\Delta \mathrm{CO}_{2} / \Delta \mathrm{O}_{2}$ は1以なの值となるてとがあらう。

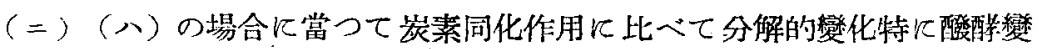


化が前者に打ち勝つ迄で沈ないが相當に活潑て行はれる場合には一方に於て 多少の酵素量の增加を見ると共に炭酸量は全く變化しないか或は却て之も增 大するといふや゙うな場合があり得る。

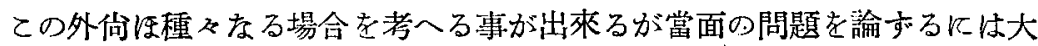
約之位の場合を考虑すれば足りるやうに思ふ。さうして今上にあげを各水尿 飞於ける $\Delta \mathrm{CO}_{2} / \Delta \mathrm{O}_{2}$ の储とてなにあげを四つの場合を比較して前者の各々 が後者の何れに當るかを檢討するてとにする。

先づ $0 \mathrm{~m}$ 及び $0.5 \mathrm{~m}$ の埸合を考へると之等つ場合飞は $\Delta \mathrm{CO}_{2} / \Delta \mathrm{O}_{2}$ が 1 以

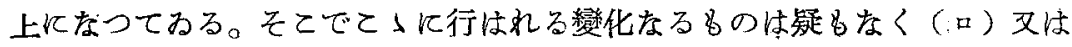
（八）の印に當るととが想像される。師ち之等の層で壮活潑なる同化作用之 活潑をる呼吸作用が行はれるに對し酸酔的變化は行はれないが行はれをよし ても微弱であつをと解すべきである。

次に $0 \mathrm{~m}$ では $\Delta \mathrm{CO} / \Delta \mathrm{O}_{2}$ が $0.5 \mathrm{~m}$ に於けるよりも大きいがその意味は呼 吸作用による酸素の消費は雨層に於て著しい差異はないが同化作用が $0.5 \mathrm{~m}$

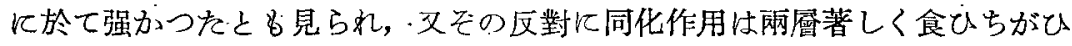
がなかつたが呼吸作用が $0 \mathrm{~m}$ では强かつをとも見られ, 正しい判斷はつきか ねる。或は $0 \mathrm{~m}$ では過飽和の酸素が炭酸よりも逃れ易く生成した酸素の一 部がかやうにして外界へ逃れるために見掛上の酸素量の增加が少く賽は同化

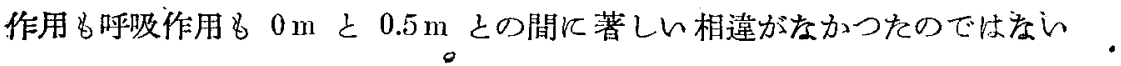

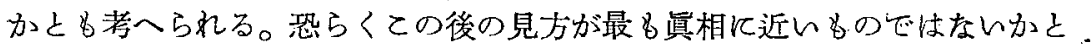
思はれる。

次に $\mathrm{pH}$ 極小層の出現した $1.0 \mathrm{~m}$ である。こよでは他層に比して微弱な

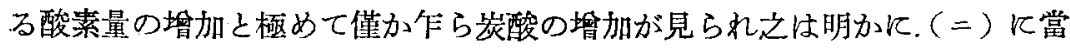
る場合で著しい醴酵之呼吸とのをめによし同化作用の强度は他層と異らず之 马見掛上の酸素增加量は減じ且つ酸素の增加に拘ら和多少とも炭酸の增加を

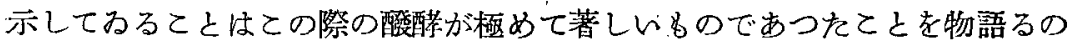
である。郎ちこの水層は $0 \mathrm{~m}, 0.5 \mathrm{~m}$ 亿對して呼吸；酸酵といふ變化の强度 於て著しい相違を示してねるのである。 
$1.5 \mathrm{~m}$ 及び $2.0 \mathrm{~m}$ では $\Delta \mathrm{CO} / \Delta \mathrm{O}_{2}$ が、に足りない。乙れば明がに.(八)

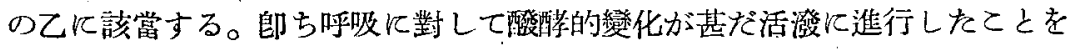
示すと共に茏素同化作用が之を洨いで更に活潑に行はれたてとを意味するも のである。

以上を綜合するに䔇間に於ては水中の代謝行程が深度を異にする水厤の間

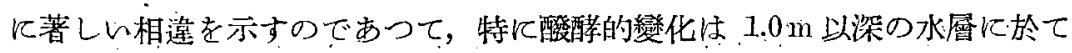

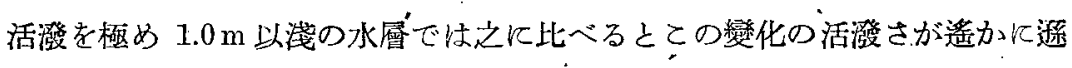

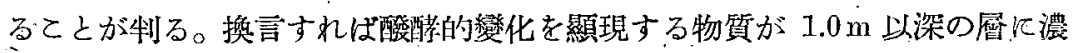

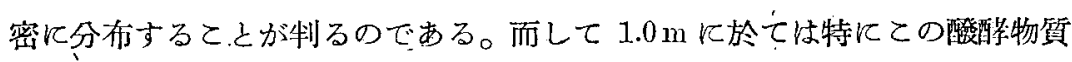
の密度が他の $1.5 \mathrm{~m}, 2.0 \mathrm{~m}$ 比して高いか或は炭素同化作用が $1.5 \mathrm{~m}$ 及び $2.0 \mathrm{~m}$ 飞對して弱いかの理由によつてていで壮炭素同化作用に當り消費され る炭酸瓦斯を補償して餘りあ岂酸の生成を見るために，他曆に於ける炭酸 量の減少と $\mathfrak{p H}$ の增加々は相反しての層では炭酸量の增加 $\mathrm{pH}$ の減少を見， 從つて $\mathrm{pH}$ 極小愿の生成を來したものと見る事が出來るのである。

かくして見る時は本報告の中心問題をるこの $\mathrm{pH}$ 逆轉の小成層の出現に就 いて著者がさきに行つを想像郎ち酸素を吸收し多量の㞸酸を放出するやうな

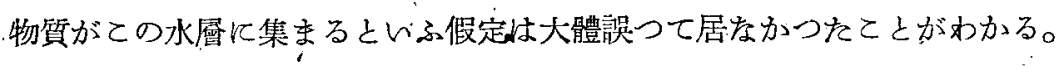
但し今间の結果壮その炭酸を放出する物質は獨り $1.0 \mathrm{~m}$ の水層に於ての引集 積するのでなく $2 \mathrm{~m}$ にも $2.5 \mathrm{~m}$ 凡名廣汎に集積するのであつて, 唯それと炭 素同化作用の强度との關係で顯著なる猍少帶として $p H$ 逆轉層が出現したも のであるととが刵明した次第である。

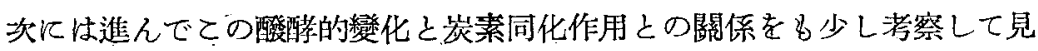
るととにしたい。

第 5 表によつて酸素の菂加量を比較すると $1.5 \mathrm{~m}$ が極大で $0.5 \mathrm{~m}$ 及び 2.0 $\mathrm{m}$ 之炕次ざ $0 \mathrm{~m}$ 恃更炕少く $1.0 \mathrm{~m}$ 快極小である。

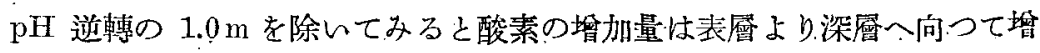
大し $\mathrm{pH}$ 逆轉層の直下で極大となりそれからは減少して對償深度にまでん でるるのを見る。同樣の關係估 1938 年 7 月 30 日の結果汸於ても見られる。 
此日の朝汃ら夕迄の增加量は $0 \mathrm{~m}, 0.87$ c.c., $1 \mathrm{~m}$,で 0.76 c.e., pH逆䡬の· 1.5 $\mathrm{m}$ 層を超えて $2.0 \mathrm{~m}$ で 1.1 e.c. の極大值に達し次いで $2.5 \mathrm{~m}$ の. 0.38 e.e.に 減少更に. $3.0 \mathrm{~m}$ てでは反對に酸素量の減少を見をのである。

そとでかららふ酸素增加量の閵係度 $\mathrm{pH}$ 極小層の出現同様この時期に於て

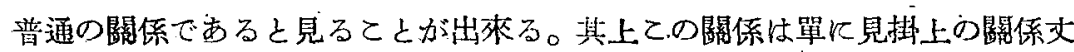
でなく實際各砶で炭素同化作用がこれと略、同じ强さの順序を以て行はれた \&のと見られる。

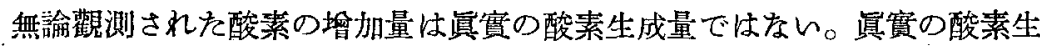
成量から呼吸により腐敗による又その他の變化により沿費されを酸素量を差 引ルものではある。・ととろがこの差引仍れる消費酸素量なるものは表層より

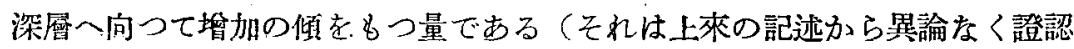
さるべき事實であるつ。 ととるで 1938 年 7 月 30 日の $2.0 \mathrm{~m}$ 層及び 1939 年 7 月 17 日の $1.5 \mathrm{~m}$ 層化（これらの層はさういふ點加ら見て消费酸素量の 大なる磿である）見撕上の酸紮增加量の極大倠が見られたのである。これは

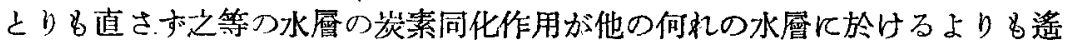
かに活撥であつたとんふととを示するのにちがひないのである。光の照度の

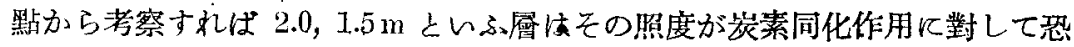

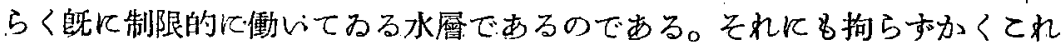

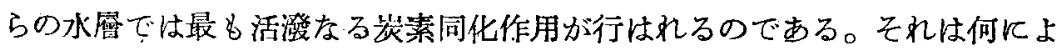
るかと云へばそれはとれらの水層に植物性プランクトンが特に著く集積す るととを想像して說明するの外はないであらう。。

そこで再び前記のプランクトン計測の結果に立ち戾つて之を检尌してみる

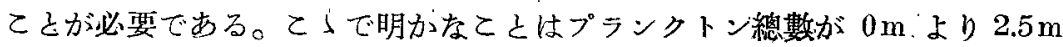
迄一樣に（1.0 m、と $1.5 \mathrm{~m}$ との間に見られる $10 \%$ 程の䁈倒を除いて）深度 と共澊加してるることである。

かわるる植物性プランクトンの分茯は確かに日光倠度の場合とは相反して酸 素增加量を深度と共に大ならしめる方向に偅く條件だするに違ひない。但し その數㑤を比較するとプランクトン總數と酸妾の增加量の變化の間に綮密な 
一致を見出士事が出來ない事が制る。即ちプランクトンは $0 \mathrm{~m} 0673,0.5 \mathrm{~m}$ の 695 に對して $\mathrm{i} .5 \mathrm{~m}$ では 959 で後者の前者に對する比は $0.71-0.72$ に

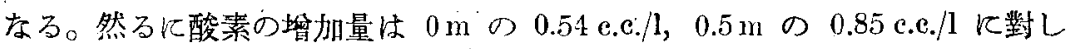
て $1.5 n$ では 2.25 c.e. $1 . l$ で後者の前者に對する比は 0.24 - 0.38 に過ぎす，

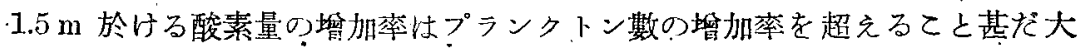
なるものがあるのである。

この間の不一致はプシンクトンを總數の代りに種類分けにし主要プンンク トンをその冬その個體數或はコロニ一數の垂遖樊化を吟味すると或度迄解釋 がつく様に見える。、。

それに就て先づ考へねばならぬのはて、闍題にされることがらが酸素生 成といふ化學的變化を量的に茂配する要素であるといふととである。そてで それはプランクトン中で單位體積中に多數に含まれる種類のもの，郎ち桨

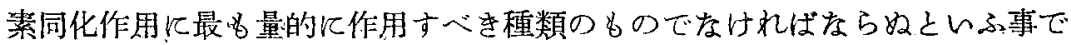
ある。

偖てか」る點から如何なる種類のbのが第一に考虑に容れらるべきがとい حば Microcystis (b) 及び (a)，Melosira，無鞭毛の綝藻類及び Sphaerocystis 之である。そこでてれらのプランクトンの上下分布を檢するときMelosira 及 は綠藻類の分布狀態が表愿に粗に，下層に向つて急に增大して行くことが認 められる。さうしてそれが吾々の問題に直接の關係を及海してみるやうに思 はしめるのである。

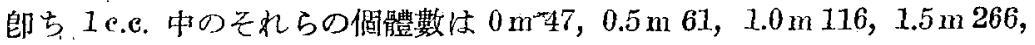

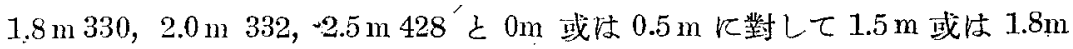
は 5.45-5.57 倍と的ふ大なる增大率を杀してるる。

之艺上の酸素增加量に比較するとをとれとこれとの間にはかなり理解し易 き關係の存在するやうに思壮れ，上にプランクトン總數の垂直變化と酸素增 加量とを比較するに㗬つて見を不一致はていではどうやら解渻するもののや うである。一方維藻類に代うて他の種類の代表的プランクトンを员て之の不

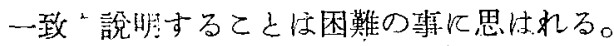


以上の諸點完考虑するとき當時の高須賀沼水中の炭素同化作用に對しては 無鞭毛の綠藻類が沃定的の役割をつとめたといふととは略々確かな事實では なんかと思はれる。

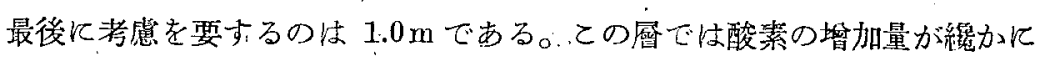
0.30 c.e. で $0-2.0 \mathrm{~m}$ 間の备層中で最小值を示してるる。とてろが上に述べ そ植物性プラシクトンはその總數量に於ても，復た炭素同化作用几對して最 も强力なる役割をつとめると思はれる無鞭毛の線藻類個體數に於ても，沈し

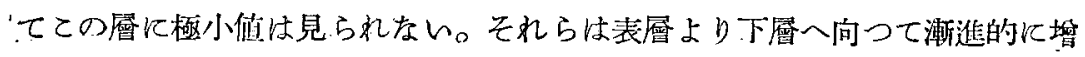
加してわる。ささうして $1 \mathrm{~m}$ では. $0.5 \mathrm{~m}$ と $1.5 \mathrm{~m}$ の中間の值をしめ殊に綠藻 類に就てその閵係を檢すれば $0.5 \mathrm{~m}$ に對してての瓷で不連續的に急激にその 量を㴰してわるのである。

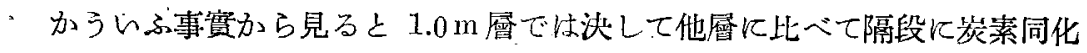
作用が抑制されて居をと估思机れ存い。恐らくその炭素同化作用の强度は $0.5 \mathrm{~m}$ に於けると $1.5 \mathrm{~m}$ に於けるとの中間程度或は日光照度の點から推論す れば，寧ろ $1.5 \mathrm{~m}$.に於けっ值に近い程の强度ですつたらうとさへ考へられさ うである。

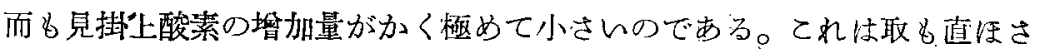
ず $1.0 \mathrm{~m}$ 曆に於ける酸素の消費的變化が甚だ强かつたと見るの外はないので ある。琶らくは $1.5 \mathrm{~m}$ に比して透かに强い酸素消費が行はれたのであらう。 その詳密者量的關係に到つては今日迄の測定結果のみを以てしては充分に 論方る譯に行かをい。てれは今後の研究によつて再び之を渝ずる機會をもち をレと思つてわる。

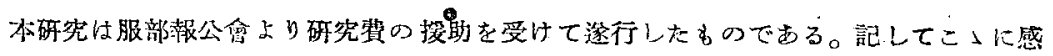
謝の意を表するてとにする。

\section{交䖒}

1. Sugawari, K. 1938: Proc. Inp. Acal, 14: 316-319.

2. Kuznetzov, S. I. 1931: Zbl. Bakt. Parasitenk., II, 83: 167-174. 